\title{
A new species of jerboa (Mammalia, Rodentia, Allactaga) from the late Miocene of Ukraine
}

\author{
Valentin Nesin and Oleksandr Kovalchuk
}

\begin{abstract}
We describe a new species of five-toed dipodoid jerboas (Allactaga fru sp. nov.) from the late Miocene of Ukraine. It differs from other extinct and recent species of this genus in size and tooth morphology. The anterior part of the M1 crown in Allactaga fru $\mathrm{sp}$. nov. is wider than the main portion of the tooth, due to the strong development of anterostyle, anteroloph and anterocone; the labial arm of the posteroloph is well developed; the strongly developed paracone is connected to both mesocone and mesostyle. The new species is also characterized by the isolated metaconid of $\mathrm{m} 1$, as well as the usually separated entoconid and mesostylid. Geological age of remains belonging to Allactaga fru sp. nov. is late Miocene, early Turolian (MN 11). This extinct species is likely the most ancient in the evolutionary line of the allactagines. This study provides new data on species diversity of allactagid jerboas in southeastern Europe during the late Miocene and is important for biogeographical history. The finding of remains belonging to Allactaga in upper Sarmatian deposits of Ukraine is consistent with climatic aridification in this region during the late Neogene and supports the hypothesis about the dispersal of small mammals (and some other vertebrates) from Asia to Europe at that time.
\end{abstract}

Valentin Nesin. Department of Paleontology, National Museum of Natural History, National Academy of Sciences of Ukraine, 15 Bogdan Khmelnitsky str., Kyiv 01030 Ukraine, inesina@mail.ru Oleksandr Kovalchuk. Department of Paleontology, National Museum of Natural History, National Academy of Sciences of Ukraine, 15 Bogdan Khmelnitsky str., Kyiv 01030 Ukraine, biologiest@ukr.net

Keywords: Rodentia; Allactagidae; Allactaga; systematics; late Miocene; Turolian; Ukraine; new species Submission: 7 December 2016 Acceptance: 20 May 2017

http://zoobank.org/6A340E9B-DBCB-47D7-B84C-993407C24C32

Nesin, Valentin and Kovalchuk, Oleksandr. 2017. A new species of jerboa (Mammalia, Rodentia, Allactaga) from the late Miocene of Ukraine. Palaeontologia Electronica 20.2.25A: 1-10

palaeo-electronica.org/content/2017/1879-miocene-jerboa-from-ukraine 


\section{INTRODUCTION}

Dipodoidea (Rodentia, Myomorpha), including saltatorial genera commonly known as jerboas, is a group of rodents whose systematics is poorly studied. This applies especially to extinct taxa. Until now, the origin and early evolutionary stages of dipodoids are not well understood. Each new publication suggests a different classification. There are contradictory opinions on this topic even in one paper (see, for example, Shenbrot et al., 1995). Zazhigin and Lopatin (2000b) based on a detailed study of the fossil remains of dipodoids from Asia proposed a classification listing Zapodidae (with Sicistinae and Zapodinae), Allactagidae (containing Allactaginae and Euchoreutinae), and Dipodidae (which includes Cardiocraniinae, Dipodinae, and the extinct Lophocricetinae). In this work, we follow this taxonomic framework.

The genus Allactaga (a member of the family Allactagidae sensu Zazhigin and Lopatin, 2000b) is known from the late Miocene of Asia and northern Africa (Mein, 2003; Shenbrot et al., 2008; Zhang et al., 2013), as well as from the late Miocene, Pliocene, and early Pleistocene of Europe. It is divided into four subgenera (Allactaga, Orientallactaga, Paralactaga, and Scarturus) and comprises 12 extant species (Wilson and Reeder, 2005). Dipodoids of the genus Allactaga have wide ranges covering steppe, semi-desert, and desert zones of Eurasia, northern Arabia, and Africa (Vinogradov, 1937; Shenbrot et al., 1995). As it was stated by Zazhigin and Lopatin (2000b), the earliest true allactagines appeared in the fossil record of Asia and rapidly spread, having dispersed into Europe and Africa during the late Miocene and Pliocene (Zhang et al., 2013).

The oldest skeletal remains of dipodoids in eastern Europe come from the Pontian lectostratotype $\left(=16^{\text {th }}\right.$ Station of Bol'shoy Fontan locality near Odesa in Ukraine) and date back to about $7 \mathrm{Ma}$ (Nesin and Nadachowski, 2001). Our finding of teeth belonging to Allactaga is older (ca. 8.7 Ma) and has interesting implications for biostratigraphy and palaeogeography of this group of small mammals.

Extant allactagines reach the left bank of the Dnieper River, and only $A$. major (probable descendant of $A$. varians from the lower Pliocene of eastern Kazakhstan) is recorded in the early Pleistocene fauna of Moldova (Gromov and Erbajeva, 1995). Here we describe a new extinct species, which is likely to be the most ancient in the evolutionary line of the allactagines.

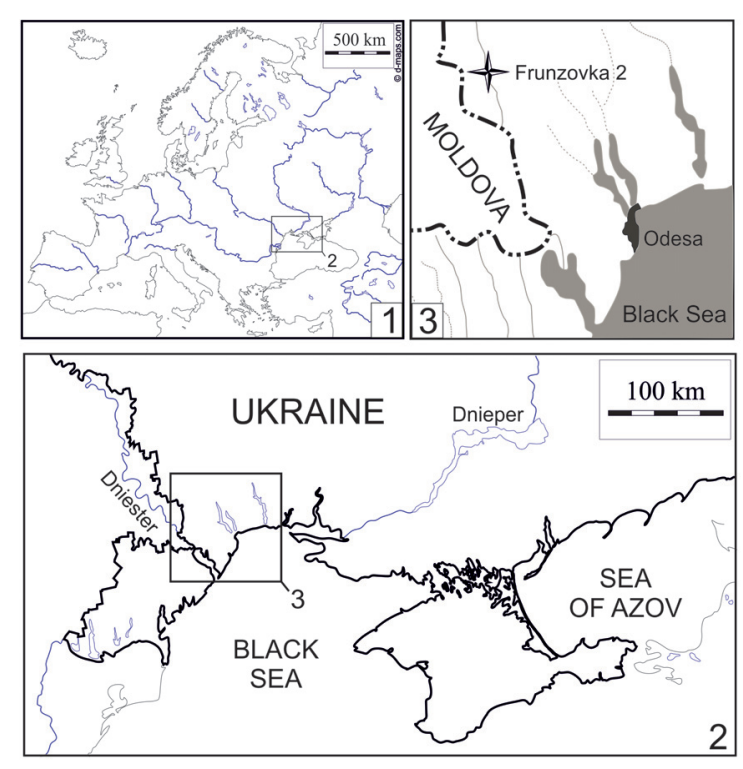

FIGURE 1. Location of the type locality Frunzovka 2, near Zakharivka (former Frunzovka) village, Odessa region, Ukraine.

\section{MATERIAL AND METHODS}

The fossil material described here is represented by isolated molars, housed in the Department of Paleontology of the National Museum of Natural History (NMNHU-P), National Academy of Sciences of Ukraine. It is derived from the late Miocene locality Frunzovka 2 in southern Ukraine and was obtained by screen-washing. Frunzovka locality is situated $2 \mathrm{~km}$ southwards from Zakharivka (former Frunzovka) village, Odesa region, southern Ukraine (Figure 1).

The fossil-bearing layer (Frunzovka 2 ) is confined to the east side of the Kuchurgan River valley. Remains of mammals and other fossils occur in pale yellow sandy-clayey gravels $(20-25 \mathrm{~cm}$ in thickness) of alluvial origin, underlain without a clear contact by sands with Mactra and other upper Sarmatian mollusks. The site is located at $10-15 \mathrm{~m}$ above the bottom of the valley. The fossils of mammals have been found in one layer formed over a relatively short time interval.

The age of the fossil-bearing deposits has been estimated as late Miocene (MN 11) because of the presence of the murid Hansdebruijnia perpusilla Storch and $\mathrm{Ni}, 2002$, the cricetids of the genus Stylocricetus and Ischymomys quadriradicatus Zazhigin, 1977 (see Nesin and Nadachowski, 2001; Nesin and Storch, 2004; Sinitsa, 2012; Nesin, 2013), the erinaceid Schizogalerix cf. sarmaticum (Lungu, 1981) as well as numerous 
ancient soricids (Rzebik-Kowalska and Nesin, 2010).

Determination of the teeth is based on comparative material from the osteological collections of NMNHU-P. The regional subdivision of eastern Paratethys stages for the late Miocene presented in this paper was based on the Stratigraphical Code of Ukraine (Teslenko, 1997), accepted by the National Stratigraphic Committee of Ukraine, while land mammal zonation follows the version presented by Mein (1999) and Nesin and Nadachowski (2001). The specimens were measured using a binocular microscope with an ocular micrometer. All measurements are given in millimeters with a precision of $0.05 \mathrm{~mm}$. The dental terminology (Figure 2) follows Zazhigin and Lopatin (2000a). Figures were drawn using the binocular stereomicroscope Wild M3C.

\section{SYSTEMATIC PALAEONTOLOGY}

Order RODENTIA Bowdich, 1821

Family ALLACTAGIDAE Vinogradov, 1925

Subfamily ALLACTAGINAE Vinogradov, 1925

Genus ALLACTAGA Cuvier, 1837

Type species. Dipus major Kerr, 1792; Eurasia, extant.

Diagnosis of the genus. Small-sized to quite large allactagine with lophodont and mainly mesodont molars. Paracone of M1 connected to endoloph, mesocone, or mesoloph. Paracone of M2 connected to mesocone or mesoloph. Metacone of M1 and M2 connected to posteroloph; the latter is reduced. Entoconid of $\mathrm{m} 1$ and $\mathrm{m} 2$ isolated from mesoconid and connected to mesolophid. Ectomesolophid of $\mathrm{m} 1$ is usually short (after Zazhigin and Lopatin, 2000b).

\section{Allactaga fru sp. nov. \\ Figure 3.1-21}

zoobank.org/FDDE9966-58BC-4439-98C0-791673AF62E6

1979 Paralactaga complicidens sp. n. (nomen nudum); Topachevsky and Skorik, p. 15.

1998 Paralactaga complicidens; Topachevsky, Nesin, Topachevsky, p. 83, tab. 3.

2001 Paralactaga complicidens; Nesin and Nadachowski, p. 124, tab. 3.

2013 Allactaga (=Paralactaga) aff. varians (Savinov, 1970); Nesin, p. 20, 153.

Topachevsky and Skorik (1979) provided a systematic review of late Miocene and early Pliocene rodents of the northern Black Sea region. They proposed new names for two species of the genus Paralactaga, one of which ( $P$. complicidens) was mentioned as occurring in the locality Frun- zovka 2. However, no type material was allocated and neither description nor figures were presented by Topachevsky and Skorik (1979). Later, this name was repeatedly used (e.g., Topachevsky et al., 1998; Nesin and Nadachowski, 2001) without any substantiation. We therefore consider $P$. complicidens as a nomen nudum. The material from Frunzovka 2 was reclassified into the genus Allactaga by Nesin (2013) and considered as belonging to a species closely related to $A$. varians. Here we assign the material from Frunzovka 2 to Allactaga fru sp. nov.

Etymology. The name refers to the initial letters of the type locality name.

Holotype. NMNHU-P 41/5549, left M1 (Figure 3.1). Department of Palaeontology, National Museum of Natural History, National Academy of Sciences of Ukraine, Kyiv.

Additional material. One P4 (NMNHU-P 41/ 5548), ten M1 (NMNHU-P 41/5550-5559), seven M2 (NMNHU-P 41/5560-5566); ten $\mathrm{m} 1$ (NMNHU-P 41/5567-5576), six m2 (NMNHU-P 41/ 5577-5582), five m3 (NMNHU-P 41/5583-5587).

Type locality. Frunzovka 2, Odesa region, southern Ukraine (Figure 1).

Geological age. Late Miocene, early Turolian, MN 11, ca. 8.7 Ma.

Measurements. Length $\times$ width: (holotype NMNHU-P 41/5549) M1 - $2.35 \mathrm{~mm} \times 1.70 \mathrm{~mm}$. For other teeth - see Table 1.

Diagnosis. A small-sized Allactaga which differs from other extinct and extant species of this genus in the following unique combination of characters: (1) the anterior part of the M1 crown is wider than the main portion of the tooth due to the strong development of anterostyle, anteroloph, and anterocone; (2) the labial arm of the posteroloph is well developed; (3) strongly developed paracone connected with mesocone and mesostyle; (4) metaconid of $\mathrm{m} 1$ is isolated on the unworn teeth; (5) entoconid and mesostylid are also separated; (6) the presence of one major anterior cusp on $\mathrm{P} 4$, completely isolated from the posterior ridge (which is arc-shaped).

Differential diagnosis. Allactaga fru sp. nov. differs from:

- A. irgizensis Zazhigin and Lopatin, 2000b by (1) strongly developed anterostyle; (2) winding (S-shaped) configuration of the medial ridge; (3) less flattened lingual tubercles of M1 and more shifted outward labial cusps; (4) earlier (in most cases) junction of the metaconid with protoconid through wear as well as a connected hypoconid and ectostylid on $\mathrm{m} 1$; (5) the ridges in the middle part of the $\mathrm{m} 1$ do not display a cruciform shape; 

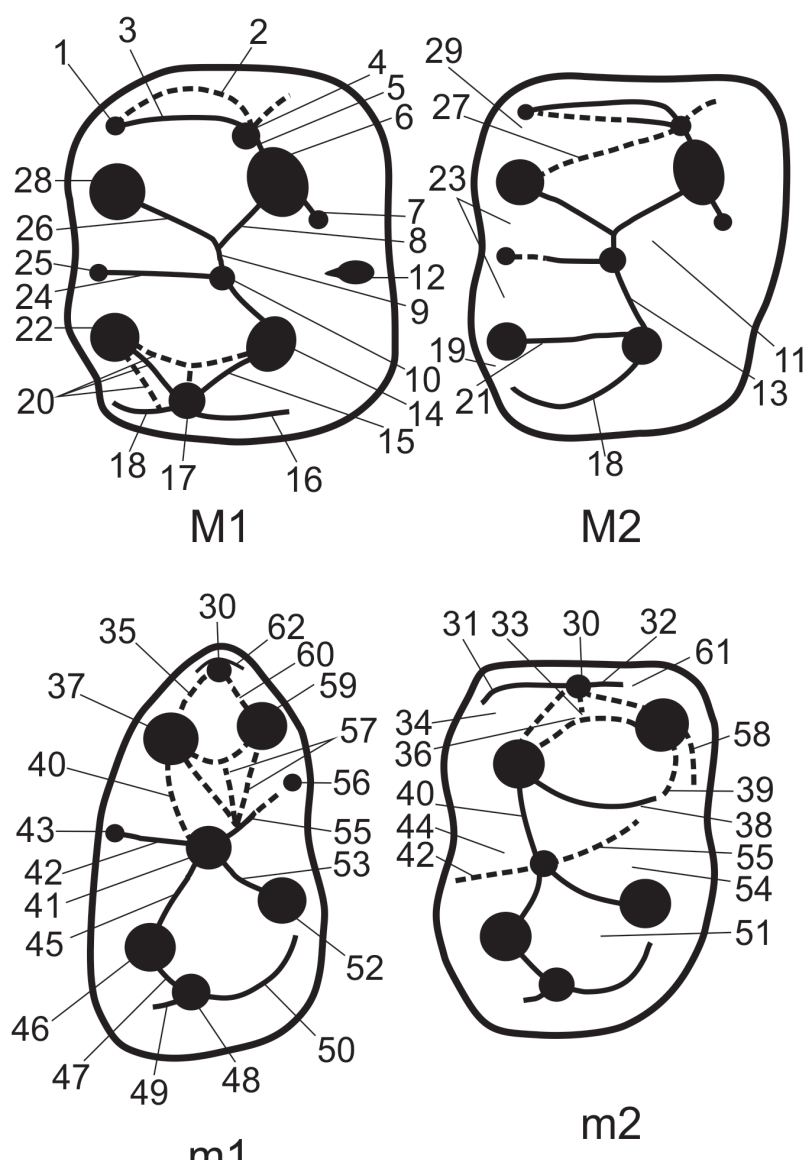

$\mathrm{m} 1$

FIGURE 2. Dental terminology used in this paper (after Zazhigin and Lopatin, 2000a). Upper dentition: 1, anterostyle; 2, anteroloph I; 3, anteroloph II; 4, anterocone; 5, anterior arm of the protocone; $\mathbf{6}$, protocone; 7, protostyle; 8, posterior arm of the protocone; 9, anterior endoloph; 10, mesocone; 11, endosinus; 12, endostyle; 13, posterior endoloph; 14 , hypocone; 15, posterior arm of the hypocone; 16, lingual arm of the posteroloph; 17, the metaconule; 18, labial arm of the posteroloph; 19, posterofossette; 20, metaloph II; 21, metaloph I; 22, metacone; 23, mesofossette; 24, mesoloph; 25, mesostyle; 26, protoloph II; 27, protoloph I; 28, paracone; 29, anterofossette. Lower dentition: $\mathbf{3 0}$, anteroconid; 31, labial arm of the anterolophid; 32, lingual arm of the anterolophid; 33, anterolophulid; 34, anterosinusid; 35, anterior arm of the protoconid; 36, metalophid I; 37, protoconid; 38, posterior arm of the protoconid; 39, metalophid II; 40, ectolophid; 41, mesoconid; 42, ectomesolophid; 43, ectostylid; 44, ectosinusid; 45, anterior arm of the hypoconid; 46 , hypoconid; $\mathbf{4 7}$, posterior arm of the hypoconid; $\mathbf{4 8}$, hypoconulid; $\mathbf{4 9}$, labial arm of the posterolophid; $\mathbf{5 0}$, posterolophid; $\mathbf{5 1}$, posterofossettid; $\mathbf{5 2}$, entoconid; $\mathbf{5 3}$, anterior arm of the entoconid; $\mathbf{5 4}$, mesofossettid; $\mathbf{5 5}$, mesolophid; 56, mesostylid; 57, endolophid; 58, metastylid crest; 59, metaconid; 60, anterior arm of the metaconid; 61, anterofossettid; 62, cingulid.

(6) more developed ectomesolophid of the $\mathrm{m} 1$; (7) ectostylid and hypoconid are strongly displaced labially from the longitudinal axis of the tooth, so the posterior part of the crown is much broader than the anterior one;

- A. minor (Zheng, 1982) by (1) more developed anterocone, anteroloph, and anterostyle, metaconule and labial posteroloph on M1 and M2; (2) developed ectostylid on $\mathrm{m} 1$ but not on $\mathrm{m} 2$;
- A. anderssoni (Young, 1927) by (1) smaller size (see Table 1); (2) close contact of paracone and endoloph on M1 and M2; (3) closer location of paracone and anterior endoloph; (4) more developed anteroloph and anterostyle on $\mathrm{M} 1$;

- A. varians (Savinov, 1970) by (1) significantly smaller size (see Table 1); (2) less expressed lophiodonty; (3) less developed lingual semihypsodonty; (4) mesodont teeth with lower crowns; (5) bigger and completely isolated anterior cusp 

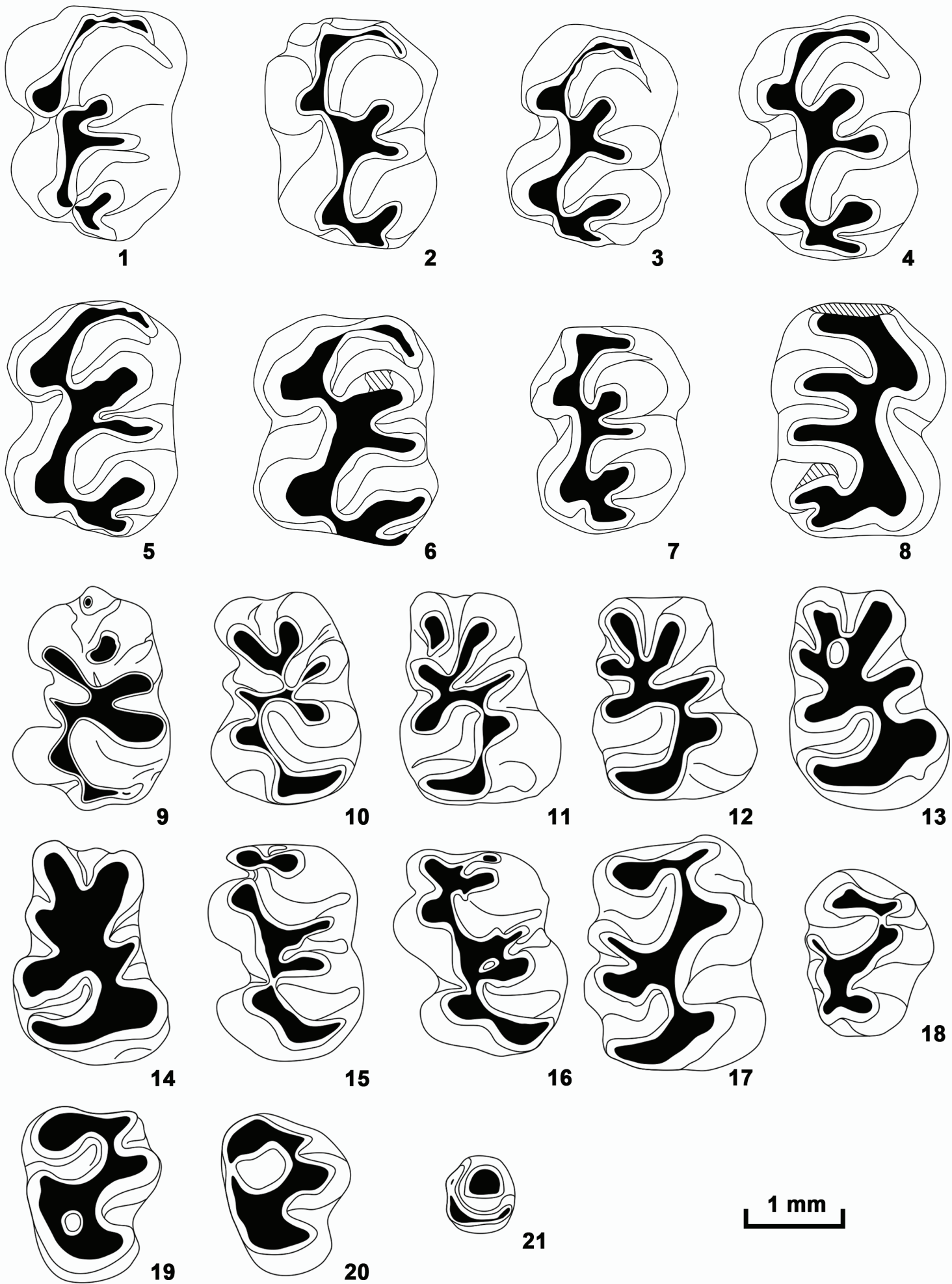

21

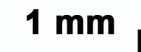

20

FIGURE 3. Molars of Allactaga fru sp. nov. in occlusal views, Frunzovka 2 locality, southern Ukraine, late Miocene (MN 11). 1, holotype, left M1 (NMNHU-P 41/5549); 2-5, left M1 (NMNHU-P 41/5550-5553). 6-7, left M2 (NMNHU-P 41/ 5557-5558). 8, right M2 (NMNHU-P 41/5566). 9-10, left m1 (NMNHU-P 41/5567-5568). 11-14, right m1 (NMNHU-P 41/5570-5573). 15-16, left $\mathrm{m} 2$ (NMNHU-P 41/5577-5578). 17, right $\mathrm{m} 2$ (NMNHU-P 41/5580). 18-20, right m3 (NMNHU-P 41/5584-5586). 21, left P4 (NMNHU-P 41/5548). 
TABLE 1. Measurements of upper and lower teeth (in $\mathrm{mm}$ ) of Allactaga from Eastern Europe and Asia.

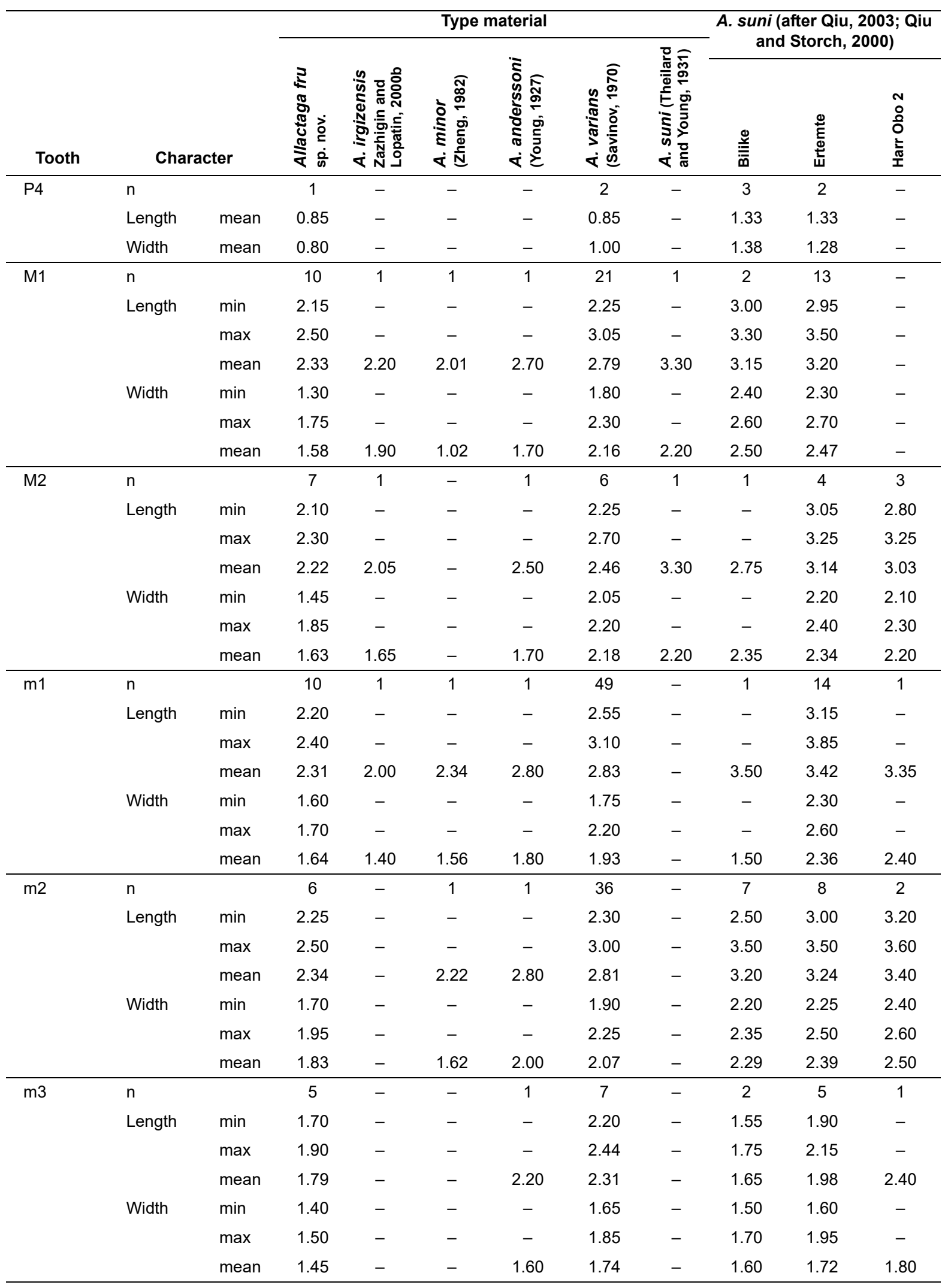


on $\mathrm{P} 4$; $(6)$ more developed anterostyle and anteroloph on $\mathrm{M} 1 ;$ (7) wider anterior part of $\mathrm{M} 1$;

- A. suni (Teilhard and Young, 1931) by (1) significantly smaller size (see Table 1); (2) close contact of paracone with other elements of tooth crown; (3) the presence of anteroconid on $\mathrm{m} 1$; (4) less developed anterocone but more developed anteroloph and anterostyle on M1.

\section{Description}

P4 (Figure 3.21) is rounded, with well-developed anterior cusps, covering approximately a third of the occlusal tooth surface. The posterior ridge is lower, bordering posterior and lingual edges of the crown. The labial valley is very narrow.

M1 and M2 (Figure 3.1-8) are similar both in size and morphology. M1 differs from M2 in the following characters: extended anterior part of the crown; narrow facet formed by the contact with P4; more developed anterostyle, anteroloph, and anterocone forming an arcuate crest, framing the anterior edge of the tooth crown. The anterocone on these teeth is well defined and bigger than the anterostyle. The anteroloph is very short and narrow. The protocone on slightly worn teeth is separated from the posterior part of the tooth; it joins the posterior arm of the endoloph when the crown is worn. The paracone is connected with the mesocone; the latter is often weakly expressed. The hypocone is large and connected in its anterior part with the mesocone via the long posterior arm of the endoloph. On slightly worn teeth, the hypocone is separated posteriorly from the joined metacone and metaconule. On worn teeth, the hypocone is connected with the two latter cusps by its short posterior arm. The metacone is also large, compressed longitudinally, and connected with a small metaconule by a short metaloph. The pointed apex of the metaconule is always directed labially, the longitudinal ridge is weakly expressed on slightly worn teeth. This ridge is clearly visible on the strongly worn M1-M2 specimens, and forms a wide arc, whose convex apex is directed anterolabially. The hypoflexus is wide, its apex pointing forward. Para- and metaflexuses are also wide; however, they curl posteriorly. The mesoflexus, and especially the posteroflexus, are narrower and shorter; they are arranged perpendicular to the longitudinal axis of the tooth.

In $\mathrm{m} 1$ (Figure 3.9-14), the anterior lobe is narrower than the posterior one due to its smaller size and more closely spaced adjacent cusps. Major and minor folds are well developed and identified at all stages of the tooth wear. Lophiodonty is mod- erately developed. The anteroconid is reduced in most cases, but sometimes is present in the form of a very small cusp on the anterior edge of the crown. The protoconid is connected to the weakly expressed mesoconid or to the short endolophid. Sometimes (in $10 \%$ of the teeth), the metaconid is in contact with the posterior part of the protoconid. The metaconid is usually connected with the mesolophid or mesostylid. The anterior arm of the entoconid is in contact with the mesoconid. On strongly worn crowns, all of these elements form a distinctive, five-petal corolla, connecting with the hypoconid through its anterior arm. The hypoconid is the largest among all cusps of this tooth; it is directly associated anteriorly with the ectostylid and posteriorly with the bucco-labially flattened hypoconulid. The postero-anterior ridge on $\mathrm{m} 1$ is traced only with the strongly worn teeth.

The $\mathrm{m} 2$ (Figure 3.15-17) is quite easily identified and differs from the $\mathrm{m} 1$ by its subsquare outline in occlusal view, the lack of an ectostylid, and the moderate development of the labial and lingual anterolophid arms. The main cusps have approximately the same size and are arranged symmetrically on the crown. On slightly worn teeth, the anteroconulid is connected with the metaconid and anterolophid. The latter disappears on strongly worn teeth, and the anteroconulid flattens anteroposteriorly. The protoconid adjoins anteriorly the anteroconulid and posteriorly the entoconid and the mesolophid, even on slightly worn teeth. An enamel island can form in the place of such connection as the tooth gets worn. The hypoconid is connected anteriorly with the entoconid, and posteriorly with the hypoconulid; the latter adjoins the longitudinally flattened posterolophid, whose pointed apex is directed anterolabially.

The m3 (Figure 3.18-20) is very small, with a triangular outline of the crown. Lingual and labial basic conids are well developed, similar in size, and individualized at all stages of the tooth wear. The lingual anterolophid is absent; the labial anterolophid is well-developed and in contact with the metaconid. This part is separated from the posterior part of the crown on unworn teeth. On the worn teeth, the anteroconulid is connected with the protoconid. The posterior fossetid forms an enamel island that quickly disappears as wear increases. At the same time, the lingual fossetid closes on the lingual edge of the crown forming a big anterior enamel island, which persists until advanced tooth wear. 
TABLE 2. Systematic composition of small mammals from the Frunzovka 2 locality (after Nesin, 2000; Nesin and Nadachowski, 2001; Nesin and Storch, 2004; Rzebik-Kowalska and Nesin, 2010; Sinitsa, 2012; Nesin, 2013).

\begin{tabular}{lll}
\hline \multicolumn{1}{c}{ Order Eulipotyphla } & \multicolumn{1}{c}{ Order Lagomorpha } & \multicolumn{1}{c}{ Order Rodentia } \\
\hline Schizogalerix cf. sarmaticum & Serengetilagus sp. & Miopetaurista sp. \\
Ruemkelia sp. & Prolagus crusafonti & Sciurotamias sp. \\
Desmaninae gen. et sp. indet. 1 & Proochotona aff. calfense & Lophocricetus aff. vinogradovi \\
"Paenelimnoecus" repenningi & Proochotona eximia & Allactaga fru sp. nov. \\
Amblycoptus oligodon & Ochotona antiqua & Hansdebruijnia perpusilla \\
Crusafontina kormosi & & Kowalskia complicidens \\
Petenyia cf. dubia & & Kowalskia aff. fahlbuschi \\
?Neomys cf. alpinoides & & Stylocricetus sp. \\
Asoriculus sp. & & Ischymomys quadriradicatus \\
\hline
\end{tabular}

\section{DISCUSSION}

Frunzovka 2 locality was discovered by V.O. Topachevsky in 1968. It yielded numerous fossil remains of small mammals including some elements of Asian ancestry, such as the rodents Hansdebruijnia (see Nesin and Storch, 2004) and Ischymomys (see Nesin, 2013), and the lagomorph Serengetilagus (see Topachevsky, 1987) (see complete faunal list given in Table 2). In total, 23 species belonging to Eulipotyphla, Lagomorpha, and Rodentia were identified (Nesin, 2000; Nesin and Storch, 2004; Rzebik-Kowalska and Nesin, 2010; Nesin, 2013).

The taxonomic composition of the Frunzovka 2 is characterized by a high proportion of species that indicate a dry climate. We hypothesize that Asian species dispersed into the northern part of the eastern Paratethys during dry periods. This is evidenced by the first appearance of allactagines (Allactaga fru sp. nov.) in the region accompanied by the dispersal of the murid Hansdebruijnia perpusilla and cricetids of the genus Kowalskia, as well as the observable spreading of Ischymomys. Such dispersals were repeated with a certain periodicity due to both the dynamics of large marine basins in the eastern Paratethys area and tectonic activity in the Mediterranean region (Syabryaj et al., 2007; Ivanov et al., 2011; Fostowicz-Frelik et al., 2012).

Palaeobotanical analysis of spores and pollen in bone-bearing sediments from the Mykhailivka locality, which is close in age to Frunzovka 2 (ca. $9.0 \mathrm{Ma}$ ), showed the existence of xerophilous floristic complexes in the middle and late Sarmatian (Prisyazhniuk et al., 2006). That time was characterized by high average annual temperatures (Pasechnyi, 1986), the expansion of steppe landscapes, and the appearance of semi-desert areas. Aridification was short-termed, since subsequent faunal assemblages indicate more temperate climates (Nesin, 2013).

The presence of Allactaga in the late Miocene of Ukraine has interesting palaeoecological and biogeographical implications. This finding provides evidence of climatic aridification in southeastern Europe during the late Neogene, which is consistent with the aforementioned data on penecontemporaneous faunas and floras.

\section{ACKNOWLEDGEMENTS}

We extend our gratitude to G. Daxner-Höck (Naturhistorisches Museum Wien, Vienna, Austria) and an anonymous reviewer for their multiple corrections, useful comments, and advice. We are also very thankful to Z. Barkasi (National Museum of Natural History, National Academy of Sciences of Ukraine, Kyiv, Ukraine) for proofreading the text. We further thank the handling editor and the whole editorial crew of Palaeontologia Electronica for the positive evaluation of our manuscript.

\section{REFERENCES}

Bowdich, T.E. 1821. An Analysis of the Natural Classification of Mammalia, for the Use of Students and Travellers. J. Smith, Paris.

Cuvier, F. 1837. Memoir on the Genera Dipus and Gerbillus. Proceedings of the Zoological Society of London, 4:141-142.

Fostowicz-Frelik, Ł., Nadachowski, A., and KowalewskaGroszkowska, M. 2012. New data on the Miocene stem lagomorph Eurolagus fontannesi, and its northernmost record. Acta Palaeontologica Polonica, $57: 1-20$.

Gromov, I.M. and Erbajeva, M.A. 1995. Mlekopitayushchie Rossii i sopredel'nykh regionov. Zaitseobraznye $i$ gryzuny (Mammals of Russia and Adjacent Regions: Lagomorpha and Rodentia). ZIN RAN Publishing, Saint-Petersburg. (In Russian) 
Ivanov, D., Utescher, T., Mosbrugger, V., Syabryaj, S., Djordjecić-Milutinović, D., and Molchanoff, S. 2011. Miocene vegetation and climate dynamics in Eastern and Central Paratethys (Southeastern Europe). Palaeogeography, Palaeoclimatology, Palaeoecology, 304:262-275.

Kerr, R. 1792. The Animal Kingdom, or Zoological System, Of The Celebrated Sir Charles Linnaeus; Class I: Mammalia. J. Murray \& R. Faulder, London.

Lungu, A.N. 1981. Gipparionovaja fauna srednego sarmata Moldavii (nasekomojadnye, zajceobraznye $i$ gryzuny) [The Hipparion fauna of the Middle Sarmatian of Moldavia (Insectivora, Lagomorpha, Rodentia)]. Izdatel'stvo Štiinca, Chișinău. (In Russian).

Mein, P. 1999. European Miocene mammal biochronology, p 73-90. In Rössner, G.E. and Heissig, K. (eds.), The Miocene Land Mammals of Europe. Verlag Dr. Friedrich Pfeil, München.

Mein, P. 2003. On Neogene Rodents of Eurasia: Distribution and Migrations, p 407-418. In Reumer, J.W.R. and Wessels, W. (eds.), Distribution and Migration of Tertiary Mammals in Eurasia. A Volume in Honour of Hans de Bruijn - DEINSEA, 10. Rotterdam, The Netherlands.

Nesin, V.A. 2000. The Most Ancient Find of a Mouse of the Genus Progonomys (Rodentia, Muridae) in the Late Miocene of Ukraine. Vestnik Zoologii, 34(45):129-132. (In Russian)

Nesin, V.A. 2013. Neogene Murinae (Rodentia, Muridae) of Ukraine. Universytets'ka knyga, Sumy. (In Russian)

Nesin, V.A. and Nadachowski, A. 2001. Late Miocene and Pliocene small mammal faunas (Insectivora, Lagomorpha, Rodentia) of Southeastern Europe. Acta Zoologica Cracoviensia, 44:107-135.

Nesin, V.A. and Storch, G. 2004. Neogene Murinae of Ukraine (Mammalia, Rodentia). Senckenbergiana lethaea, 84(1-2):351-365.

Pasechnyi, G.V. 1986. Palaeogeographical Staging (on Example of the Neogene of Ukraine). Thesis for obtaining a scientific degree Dr. Geol.-Miner. Sci. Kyiv. (In Russian)

Prisyazhniuk, V.A., Kovalenko, V.A., Liulieva, S.A., and Siabriay, S.V. 2006. Cross-section of Sarmatian deposits in the Mikhailovsky quarry - a unique point of the direct correlation of marine and continental sediments. Geological journal, 1:64-75. (In Russian)

Qiu, Zh. 2003. The Neogene mammalian faunas of Ertemte and Harr Obo in Inner Mongolia (Nei Mongol), China. - 12. Jerboas - Rodentia: Dipodidae. Senckenbergiana lethaea, 83(1/2):135-147.

Qiu, Zh. and Storch, G. 2000. The early Pliocene micromammalian fauna of Bilike, Inner Mongolia, China (Mammalia: Lipotyphla, Chiroptera, Rodentia, Lagomorpha). Senckenbergiana lethaea, 80(1):173-229.

Rzebik-Kowalska, B. and Nesin, V.A. 2010. Erinaceomorpha and Soricomorpha (Insectivora, Mammalia) from the Late Miocene of Ukraine. Institute of Sys- tematics and Evolution of Animals, Polish Academy of Sciences. Drukarnia Kolejowa, Kraków.

Savinov, P.F. 1970. The Dipodoidea (Rodentia, Mammalia) from the Neogene of Kazakhstan, p. 31-134. In Materialy po evolyutsii nazemnykh pozvonochnykh (Materials on the Evolution of Terrestrial Vertebrates). Nauka, Moscow. (In Russian)

Shenbrot, G.I., Sokolov, V.E., Heptner, V.G., and Kowalskaya, Yu.M. 1995. Mlekopitayushchie Rossii i sopredel'nykh regionov. Tushkanchikoobraznye (Mammals of Russia and Adjacent Regions: Dipodoidea). Nauka, Moscow. (In Russian).

Shenbrot, G.I., Sokolov, V.E., Heptner, V.G. and Kowalskaya, Y.M. 2008. Jerboas. Mammals of Russia. Science Publishers Inc., Enfield, USA.

Sinitsa, M.V. 2012. Cricetids (Mammalia, Rodentia) from the Late Miocene locality Palievo, Southern Ukraine. Vestnik Zoologii, 46(2):137-147. (In Russian)

Storch, G. and Ni, X. 2002. New Late Miocene murids from China (Mammalia, Rodentia). Geobios, 35:515521.

Syabryaj, S., Utescher, T., Molchanoff, S., and Bruch, A.A. 2007. Vegetation and palaeoclimate in the Miocene of Ukraine. Palaeogeography, Palaeoclimatology, Palaeoecology, 253:153-168.

Teilhard de Chardin, P. and Young, C.C. 1931. Fossil mammals from northern China. Palaeontologia Sinica, Ser. C, 9(1):1-87.

Teslenko, Yu.V. 1997. Stratigraphic Code of Ukraine. Kyiv. (In Ukrainian)

Topachevsky, I.V. 1987. The first find of the genus Serengetilagus representative (Lagomorpha, Leporidae) from Pliocene deposits of the Eastern Europe. Vestnik Zoologii, 6:48-51. (In Russian)

Topachevsky, V.A., Nesin, V.A., and Topachevsky, I.V. 1998. Biozonal microtheriological scheme (stratigraphic distribution of small mammals - Insectivora, Lagomorpha, Rodentia) of the Neogene of the northern part of the East Parathetis. Vestnik Zoologii, 32:76-87. (In Russian)

Topachevsky, V.A. and Skorik, A.F. 1979. A systematic review of the Late Miocene and Early Pliocene rodents (Mammalia, Rodentia) of the north Black Sea area. Vestnik Zoologii, 6:11-17. (In Russian)

Vinogradov, B.S. 1925. On the structure of the external genitalia in Dipodidae and Zapodidae (Rodentia) as a classificatory character. Proceedings of the Zoological Society of London, 1925(1):572-585.

Vinogradov, B.S. 1937. Jerboas, Fauna of the USSR, New Ser. no. 13: Mammals. Academy of Sciences of the USSR, Moscow-Leningrad. (In Russian)

Wilson, D.E. and Reeder, D.A.M. (eds.). 2005. Mammal Species of the World. A Taxonomic and Geographic Reference ( $3^{\text {rd }}$ ed.), Johns Hopkins University Press, Baltimore.

Young, C.C. 1927. Fossile Nagetiere aus Nord China. Palaeontologia Sinica, Ser. C, 5(3):1-82.

Zazhigin, V.S. 1977. Ischymomys gen. nov. in Gromov, V.I. and Polyakov, I.Ya. (eds.), Fauna of the USSR. 
Mammals, III, 8: voles (Microtinae). Nauka, Leningrad. (In Russian).

Zazhigin, V.S. and Lopatin, A.V. 2000a. The history of the Dipodoidea (Rodentia, Mammalia) in the Miocene of Asia: 1. Heterosminthus (Lophocricetinae). Paleontological Journal, 34(3):319-332.

Zazhigin, V.S. and Lopatin, A.V. 2000b. The history of the Dipodoidea (Rodentia, Mammalia) in the Miocene of Asia: 3. Allactaginae. Paleontological Journal, 34(5):553-565.
Zhang, Q., Xia, L., Kimura, Y., Shenbrot, G., Zhang, Z., Ge, D., and Yang, Q. 2013. Tracing the origin and diversification of Dipodoidea (Order: Rodentia): Evidence from fossil record and molecular phylogeny. Evolutionary Biology, 40(1):32-44.

Zheng, S.H. 1982. Middle Pliocene micromammals from the Tianzhu Loc. 80007 (Gansu Province). Vertebrata PalAsiatica, 20(2):138-147. (In Chinese, with English summary) 